\title{
Penerapan Prinsip Kekebalan Negara Terhadap Badan Usaha Milik Negara
}

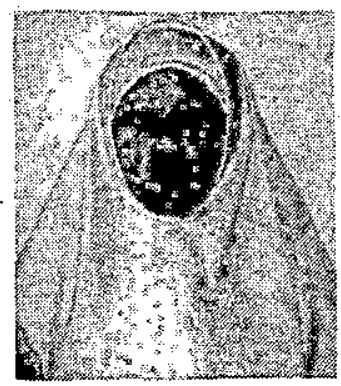

Oleh: Ni'maful Huda

Dalam beberapa kasus terlihat, bahwa penerapan prinsip kekebalan negara terhadap BUMN masih bersifat kasuistis, karena memang, dalam hal itu

belum ada standar/kriteria yang jelas. Ni'matul Huda, memberikan aksentuasi bahwa amat penting di masa mendatang melalui kaidah-kaidah hukum internasional perlu diterapkan semacam general conditions dan guidelines yang akan digunakan sebagai pedoman dalam penerapan prinsip kekebalan negara yang dibentuk atas dasar kesepakatan negara-negara melalui perjanjian internasional.

\section{Pendahuluan}

Pada permulaan berkembangnya imunitas (kekebalan) negara telah diterima bahwa suatu negara secara mutlak tidak dapat digugat di hadapan forum hakim negara lain. Praktek demikian didasarkan atas penerimaan doktrin imunitas mutlak (absolute immunity) dimana sejak abad 19 berbagai keputusan hukum telah mengecualikan negara lain dari yurisdiksi pengadilan nasional. Pendapat demikian dikemukakan misalnya oleh Gentili, Grotius, Bynkershoek dan Vattel. ${ }^{1}$

Namun dalam perkembangan berikutnya imunitas negara terhadap yurisdiksi negara lain menjadi tidak mutlak atau terbatas. Hal ini terjadi setelah munculnya perusahaan-perusahaan milik negara yang memonopoli perdagangan internasional dan berbagai bentuk perdagangan yang diselenggarakan oleh negara telah menyebabkan perubahanperubahan yang sangat penting dalam hukum kekebalan negara, karena negara semakin terlibat dalam pengawasan ekonomi nasional.

Demikian pula Act of State Doctrine,

1. Sompong Suchantkul, State Immunities and Trading Activities in Intemational Law, Frederick A. Praeger inc., Publisher, New York, 1959, p.3 No. 1-4. 
pedagang sebagaimana yang dituduhkan oleh serikat buruh Amerika Serikat. Dalam tingkat banding di Ninth Circuit San Fransisco, hakim menetapkan pengadilan negara bagian Los Angeles tidak berwenang mengadili tindakan-tindakan pemerintah negara-negara OPEC, termasuk Republik Indonesia. Jadi, yang ditekankan pada tingkat banding ini adalah tindakan-tindakan pemerintah negara-negara OPEC dengan nyata berlaku act of state doctrine. Lain halnya pada tingkat pertama (Dictrict Court Los Angeles), yang menyatakan dirinya tidak berwenang untuk mengadili perkara OPEC versus IAM berdasarkan teori kekebalan.

\section{Penerapan Prinsip Kekebalan Negara}

Dalam perkembangan lebih lanjut, hubungan antar bangsa yang tunduk kepada prinsip-prinsip hukum publik, ternyata tidak saja dilakukan oleh negara sebagai subyek hukum internasional utama, tetapi telah pula melibatkan interaksi Badan Usaha Milik Negara (BUMN), baik antar perusahaan negara di suatu negara dengan BUMN dengan perusahaan swasta. Dalam pembahasan ini, ada satu hal yang menarik untuk dianalisis, yaitu bagaimana status BUMN dalam kaitannya dengan penerapan prinsip kekebalan negara.

Aktivitas ekonomi BUMN yang bersifat internasional/ transnasional mengandung unsur-unsur asing (foreign elements), ternyata membawa pengaruh terhadap prinsip kekebalan negara yang terdapat dalam hukum internasional. Berdasarkan hal ini, muncul pertanyaan; "Sejauhmana BUMN dapat diperlakukan sebagai bagian negara, sehingga BUMN berhak atas penerapan prinsip kekebalan negara ? Hal ini akan membawa akibat lebih jauh. Apakah suatu pengadilan negara asing mempunyai yurisdiksi memeriksa dan memutus sengketa internasional yang melibatkan BUMN sebagai pihak yang digugat?"

Munculnya persoalan di atas, dilatár belakangi pemikiran, bahwa penerapan prinsip kekebalan negara tidak serta merta dapat diterapkan terhadap BUMN. Dalam hal ini diperlakukan yang berbeda dan lebih spesifik.

Berkaitan dengan masalah ini pula, upaya jalan keluar diberikan dengan menetapkan kriteria, apakah BUMN tersebut merupakan milik negara, maka BUMN tersebut berhak atas penerapan prinsip kekebalan negara yang berlaku menurut hukum internasional publik. Sebaliknya, apabila BUMN dikualifikasi sebagai bukan milik negara, maka BUMN tersebut tidak berhak atas kekebalan negara. Persoalan BUMN yang demikian diselesaikan menurut hukum perdata internasional, bukan hukum internasional publik.

Untuk mengetahui bagaimana kriteria suatu perusahaan dapat dikualifikasi sebagai BUMN, Moses Aldrin Kimuli mengatakan bahwa ada dua karakteristik utama mengenai perusahaan negara: Pertama, sebuah perusahaan ini berbeda dari satu negara dengan negara lain, dari satu perusahaan ke perusahaan lain. Jadi perusahaan negara disamping menanggung tugas pemerintah juga melaksanakan fungsi-fungsi pemerintah. Kedua, sebuah perusahaan negara sepenuhnya dimiliki oleh pemerintah dalam pengertian bahwa tidak ada pemilik atau hak pemilikan lain yang di tangan individu-individu atau lembaga-lembaga swasta. Ketiga, sebuah perusahaan negara merupakan perusahaan berbadan hukum yang dibiayai melalui sumber-sumber pemerintah dan di bawah pengawasan pemerintah. ${ }^{6}$

6. Moses Aldrin Kimuli, The Aplication of The Doctrine of Foreign Sovereign/State Immunity to Public Corporation, Lawasia, 1986, Joumal of The Law Association for Asia and Pacific Published by The Faculty of Law, South Wales institute of Technology, him.35-36. 
pada permulaan diterapkannya menolak untuk menilai keabsahan suatu tindakan atau perbuatan dari negara lain yang telah diakuinya. Namun suatu negara berdaulat, meskipun telah diakui dapat dituntut di hadapan forum pengadilan asing apabila ia telah bertindak bukan sebagai negara (publikc act) akan tetapi ia bertindak sebagai pedagang (privat act).

Pada penerapan prinsip kekebalan negara yang melibatkan negara/pemerintah sebagai subyek hukum internasional, kita menggunakan dua kriteria, yaitu kriteria iure imperii dan iure gestionis. Suatu negara nasional berhak atas perlindungan berdasarkan prinsip kekebalan negara apabila negara melakukan tindakan atau perbuatan dalam kapasitas dan kualitasnya sebagai negara berdaulat. Artinya, negara berada dalam status jure imperii. Sebaliknya, perlindungan atas dasar prinsip kekebalan negara tidak dapat diberikan oleh suatu negara asing terhadap kepentingan nasional negara, apabila negara tersebut melakukan tindakan sebagai pedagang yang melakukan Commercial Act, artinya, negara berada dalam status jure gestionis. ${ }^{2}$ Dalam jure gestionis ini negara tidak lagi berdaulat, kedaulatannya telah dikurangi dan ia dapat dihadapkan di pengadilan asing (terjadi semacam erosi kedaulatan).

Meskipun demikian, timbul kesulitan mengenai apa yang sesungguhnya yang dianggap sebagai commercial activity itu. Kesulitan ini tampak dalam rangka memberlakukan teori secondary immunity, yang dalam prakteknya dapat dianggap sebagai commercial activit, dan dapat pula dianggap sebagai tindakan pemerintah yang lebih bersifat hukum publik. Dalam hal ini dapat disaksikan dalam foreign sovereign immunity act of united state 1976, dan yurisprudensi Amerika Serikat sekitar act of state doctrine. ${ }^{3}$

$\mathrm{Hal}$ ini dapat ditunjukkan pada kasus OPEC dan negara-negara anggotanya yang digugat oleh serikat buruh di.Amerika Serikat (International Associations of Machinist and Aerospace Wokers/IAM) di hadapan District Court Los Angeles, California pada tahun 1979-1981, timbul permasalahan hukum yang serupa.

Pada tingkat pertama (District court LA, California), jawaban yang diberikan secara tepat oleh pengadilan, bahwa negara-negara berdaulat bersangkutan telah menyangkal adanya yuridiksi District Court California ini. Sebagai negara-negara merdeka dan berdaulat, tidak mungkin mereka digugat di hadapan forum pengadilan negara berdaulat lainnya (Amerika Serikat). Secara tepat pula berdasarkan sovereing immunity, tidak dapat diajukan Republik Indonesia sebagai pihak dalam perkara tersebut. ${ }^{4}$

Di samping itu, kita saksikan bahwa dalam tingkat banding dipandang pula, bahwa tindakan-tindakan negara-negara berdaulat tidak dapat diuji oleh hakim-hakim dari negara berdaulat lainnya. Dengan kata lain, tindakan-tindakan Republik Indonesia Cs., melalui para menteri (perminyakan/ perdagangan) yang telah mengadakan penentuan pembatasan produksi minyak negara-negara OPEC tidak dapat diuji keabsahannya oleh para hakim negara bagian Amerika Serikat. ${ }^{5}$ Karena para Menteri dimaksud bertindak dalam kapasitasnya sebagai negara/pemerintah, bukan sebagai

2. Sudargo Gautama, Hukum Perdata dan Dagang Intemasional, Alumni, Bandung, 1980, him.3, Selanjutnya lihat Yudha Bhakti Ardhiwisastra, Penerapan Sovereign dan Act of Atate Doctrine Negara Berdaulat di Hadapan Pengadilan Asing, Tesis, UNPAD, Bandung, 1982, him.18.

3. Sudargo Gautama, Soal-soal Aktual Hukum Perdata Intemasional, Alumni, Bandung, 1981, hlm.215.

4. Sudargo Gautama, Aneka Masalah Hukum Perdata Intemasional, Alumni, Bandung, 1985, h/m.29-30.

5. Ibid., him. 28 . 
Karakteristik dan pengertian perusahaan negara sebagaimana disebutkan oleh Moses Aldrin Kimuli di atas, nampaknya sesuai dengan bentuk perusahaan negara di negara kita, utamanya Pertamina.

Dalam sistem hukum di Indonesia, Pertamina memang merupakan bentuk perusahaan negara yang bersifat khusus. Sejak tahun 1969 kita mengenal tiga bentuk perusahaan negara yakni, Perusahaan Jawatan (Perjan), Perusahaan Umum (Perum), dan Perusahaan Perseroan (Persero). Ketiga bentuk perusahaan negara ini memiliki sifat dan karakteristik sendirisendiri. Perjan misalnya, dengan "public services"nya, pengabdian dan pelayanan kepada masyarakat; Perum melayani kepentingan umum dan sekaligus memupuk keuntungan; dan Persero melulu memupuk keuntungan. ${ }^{7}$

Mengenai kekhususan Pertamina ini dapat dilihat dari undang-undang pembentukannya yang tertuang dalam undang-undang No. 8 tahun 1971 jo undangundang No. 10 Tahun 1974. Dalam UU pembentukannya antara lain disebutkan bahwa tujuan pendirian Pertamina adalah untuk membangun dan melaksanakan pengadaan minyak dan gas bumi dalam arti seluas-luasnya untuk sebesar-besarnya kemakmuran rakyat dan negara serta menciptakan ketahanan nasional. Modal perusahaan adalah kekayaan negara yang dipisahkan dari APBN dan modal perusahaan ini terbagi atas saham-saham.

Pertamina dalam mengadakan kerjasama dengan pihak lain dalam bentuk "contract production sharing". Selanjutnya dalam ketentuan peralihan disebutkan bahwa segala hak dan kewajiban serta akibat-akibat yang timbul dari suatu perjanjian/kontrak antara Pertamina dengan pihak lain beralih menjadi hak dan kewajiban perusahaan.

Sebagaimana diketahui pada tahun 1975. Pertamina menghadapi krisis keuangan yang sangat parah karena hutang yang harus dibayar untuk membiayai proyekproyek besar berada di luar kemampuannya. Dalam rangka menanggulangi krisis tersebut, pemerintah Indonesia telah mengambil langkah-langkah yang cukup berani yakni dengan jalan mengambil alih tanggung jawab hutang dan urusan Pertamina menjadi urusan resmi pemerintah.

Inti tindakan pemerintah RI antara lain mengambil alih persoalan Floating Fertilizer Plant yang kemudian secara teknis diserahkan kepada Direktorat Jenderal Petrokimia dan ditindaklanjuti dengan mengadakan renegosiasi serta peninjauan kembali segala sesuatunya. "Tindakan pemerintah Indonesia ini telah berhasil menggagalkan upaya pihak yang menggugat dari proses penyitaan barang-barang milik Pertamina dan tindakan tersebut dipandang sebagai tindakan sebuah pemerintah dari suatu negara yang berdaulat yang memiliki kebebasan untuk mengatur segala sesuatunya (iure imperii). Barang-barang dimaksud walaupun pada awalnya milik Pertamina sebagai badan hukum tersendiri, tetapi titel hukum dari barang-barang dimaksud walaupun pada awalnya milik Pertamina sebagai badan hukum tersendiri, tetapi titel hukum dari barang-barang itu telah beralih kepada Ditjen Petrokimia (Departemen dari pemerintah), maka tidak dapat dilakukan sitaan terhadapnya. ${ }^{9}$

Tindakan pemerintah mengambil alih tanggungjawab, dimana seharusnya dipikul

\footnotetext{
7. A. Hamid S: Attamimi, BUMN Kedudukan Ekonomis Yuridis dan Pengelolaan Keuangannya, Makalah dalam Seminar Nasional Keuangan negara II, diselenggarakan oleh Jurusan Hukum Administrasi Negara, FH-UI, pada tanggal 28 Februari 1991, di Jakarta.
}

8. Yudha Bhakti A., op.cit., h/m 47.

9. lbid. 
oleh Pertamina sebagai satu badan hukum yang mandiri didasari oleh beberapa pertimbangan, baik yang bersifat politis maupun yuridis. Pertimbangan-pertibangan itu antara lain: (a) Pertamina akan bangkrut karena persoalan yang dihadapi di luar batas kemampuan untuk mengatasinya; (b) kebangkrutan Pertamina akan menimbulkan akibat yang serius terhadap keadaan ekonomi dan keuangan negara.

Berdasarkan pertimbangan itu, pemerintah disamping melakukan pembenahan intern perusahaan yang dianggap mismanagement, juga membantu perusahaan negara ini menyelesaikan secara maksimal beban yang harus dipikulnya serta melakukan langkah-langkah konkrit berupa penetapan agar diadakan penjualan sebagian dari kekayaan Pertamina yang berlebihan, baik kepada pemerintah maupun kepada pihak swasta. ${ }^{10}$

Secara yuridis kasus Pertamina ini memang menempatkan posisi pemerintah Indonesia sebagai suatu negara yang memiliki "sovereign immunity" dan apa yang dilakukan Presiden Rl dalam bentuk Keppres dianggap sebagai memenuhi prinsip "act of state doctrine" sehingga Pertamina sebagai perusahaan negara diberi hak kekebalan.

Pemberian hak kekebalan berdasarkan asas act of state doctrine terhadap kasus Pertamina sebagai perusahaan negara tidak terlepas dari pertimbangan yang bersifat politis. Bidang usaha utama Pertamina adalah minyak dan gas bumi. Ini merupakan sumber devisa negara $\mathrm{Rl}$ yang dominan sebagaimana terlihat dari APBN. Oleh karena itu, tindakan .pemerintah mengambil alih tanggungjawab tersebut tidak bisa dilepaskan dari pertimbangan kepentingan umum rakyat Indonesia dan karenanya wajar jika ia dikualifisir sebagai tindakan yang bersifat publik.

Pertamina dalam rangka mengembangkan usahanya tidak terlepas dari ikatan kerja sama dengan pihak ketiga. Jika dilihat dari kerangka ini, apa yang dilakukan Pertamina memang lebih mengarah kepada commercial activity. Akan tetapi tindakan Presiden Rl mengatasi krisis Pertamina adalah tindakan penyelamatan yang bersifat melindungi public interest, dan karenanya sama sekali tidak memiliki unsur komersial.

Penerapan asas act of state doctrine oleh suatu pengadilan asing dewasa ini banyak pula dipengaruhi oleh "hubungan baik dan kepentingan" antara pemerintah dimana pengadilan menjalankan yurisdiksinya dengan pihak-pihak pemerintah yang terkait dengan kasus yang sedang diperiksa. Praktek pengadilan yang meminta pendapat eksekutif terlebih dahulu sebelum mengambil keputusan hukum memperkuat estimasi ini. Oleh karena itulah pembahasan mengenai act of state doctrine disamping terdapat apa yang dinamakan balancing approach juga ia berkaitan dengan masalah diplomatik sehingga tidak semata-mata persoalan hukum internasional. ${ }^{11}$

Kriteria perusahaan negara yang dikaitkan dengan pemilikan saham sebagaimana disebutkan oleh Moses Aldrin Kimula kelihatannya masih memiliki kelemahan. Sebab dalam praktek ada pula perusahaan negara yang sahamnya tidak sepenuhnya dimiliki pemerintah, meskipun pemerintah tetap sebagai pemegang saham mayoritas. Misalnya perusahaan British $\mathrm{Pe}-$ troleum milik pemerintah Inggris, dimana saham pemerintah hanya 35 persen.

Perusahaan British Petroleum ini pernah mendapat panggilan pengadilan dalam kasus

10. Romadhon K.H., Otobiografi Soeharto Pikiran, Ucapan dan Tindakan Saya, PT Cipta Lamtorogung

Persada, Cet. II, 1989, him.304-306.

11. Yudha Bhakti A., Immunitas negara dan Doktrin Tindakan Negara, Makalah Bahan Penataran Prinsipprinsip Hukum Intemasional, FH-UNPAD, Bandung, 16-28 November 1992, hlm.44. 
reinvestigation of word petroleum arrangement, perusahaan Anglo Iranian Oil Co.Ltd. atau lebih dikenal sebagai British Petroleum. Perusahaan ini menolak memenuhi panggilan pengadilan Distrik of Columbia Amerika Serikat dengan alasan bahwa sebagai alat perlengkapan pemerintahan Inggris, perusahaan ini kebal terhadap yurisdiksi pengadilan Amerika Serikat.

Pengadilan berpendapat bahwa perusahaan itu tidak bisa dipisahkan dari pemerintah Inggris dan menegaskan bahwa kekebalan pemerintah Inggris diberikan kepada perusahaan itu. Dasar pertimbangan pengadilan ialah terdapatnya fakta bahwa perusahaan itu dikendalikan pemerintah dan perusahaan itu melaksanakan fungsi-fungsi pemerintah yang penting, yakni menjamin penyediaan bahan bakar; minyak mentah, dan produk-produk lain bagi Angkatan Laut Inggris. ${ }^{12}$

Oleh karena itu, kriteria berdasarkan "milik negara" ini dianggap kurang memuaskan, sebab tidak ada kriteria yang berlaku universal tentang apa yang dimaksud dengan milik negara menurut hukum internasional disamping itu, struktur pemilikan yang berlaku di setiap negara berbeda satu sama lain. Hal ini sering mempersulit proses pembuktian. Kualifikasi lex personalis dan lex fori yang sering diterapkan dalam proses pemeriksaan dalam sengketa perdata internasional tidak begitu saja dapat diterapkan disini. Akibatnya proses penerapan prinsip kekebalan negara lebih banyak mengandalkan ketrampilan dan kelihaian seorang pengacara yang menangani perkara dan argumen-argumen yang bersifat sosiologis-politis dari negaranegara nasional.

Dalam menjawab permasalahan ini digunakan kriteria antara lain yaitu, apakah BUMN tersebut merupakan organ negara atau bukan ? Apabila BUMN dikualifikasi sebagai organ negara, maka BUMN berhak atas penerapan prinsip kekebalan negara. Sebaliknya, apabila BUMN tersebut tidak berhak atas penerapan prinsip kekebalan negara. Namun hal ini pun dianggap kurang memuaskan, terbukti dalam kasus Trendtex yang melibatkan Bank Central Nigeria dengan perusahaan Swiss.

Dalam kasus Trendtex, permohonan Bank Central Nigeria (yang dikualifikasi sebagai organ negara) telah ditolak oleh pengadilan untuk minta hak imunitasnya. Dalam kasus ini, Bank Central Nigeria telah mengeluarkan Letter Of Credit (L/C) melalui Midland Bank di London untuk kepentingan sebuah perusahaan Swiss dalam rangka pembayaran semen yang dijual perusahaan tersebut kepada sebuah perusahaan di Inggris.

Bank Central Nigeria telah meyakinkan perusahaan Swiss itu bahwa L/C itu sah. Berdasarkan keyakinan itu perusahaan Swiss membeli semen dan menjual semen tersebut kepada perusahaan Inggris serta mengapalkannya ke Nigeria. Ternyata Bank Central Nigeria menolak membayar sehingga perusahaan Swiss mengajukan gugatan. Alasan Bank Central Nigeria bahwa ia merupakan badan pemerintahan Nigeria dan berhak atas kekebalan tidak bisa diterima oleh pengadilan.

Menurut pertimbangan pengadilan, Bank Central Nigeria didirikan sebagai badan usaha yang terpisah dari pemerintah dan bukan merupakan alat, tangan, atau badan pemerintahan Nigeria sehingga ia tidak berhak memperoleh kekebalan. Selanjutnya ditegaskan pula oleh pengadilan bahwa sekaligus bank itu merupakan bagian dari pemerintahan Nigeria, namun karena hukum internasional waktu itu tidak mengakui kekebalan atas gugatan atau tuntutan bagi

12. Moses Aldrin Kimuli, op.cit., him.44. 
sebuah departemen pemerintah dalam kaitannya dengan transaksi komersial, oleh karenanya Bank Central tidak berhak atas kekebalan yang berhubungan dengan $L / C{ }^{13}$

Dari ketiga kasus di atas, ternyata penerapan prinșip kekebalan negara terhadap BUMN bersifat sangat kasuistis. Hal itu terjadi karena hukum internasional belum mempunyai rumusan yang dapat dijadikan pedoman mengenai kriteria apakah tindakan hukum sebuah perusahaan negara (dalam batas-batas tertentu bisa mengklaim sebagai tindakan resmi negara) bersifat juri imperij ataukah bersifat juri gestionis.

\section{Penutup}

Hingga saat ini belum ada suatu standar atau kriteria yang jelas mengenai penerapan prinsip kekebalan negara dalam kaitannya dengan BUMN. Tolok ukur "milik negara" dan "organ negara" yang digunakan untuk menentukan apakah suatu BUMN berhak atau tidak terhadap penerapan prinsip kekebalan negara atas tindakan yang dilakukannya seringkali menimbulkan interpretasi dan penilaian yang berbedabeda. Hal ini terjadi karena kondisi obyektif masing-masing negara atau perusahaan negara berbeda bergantung pada latar belakangnya, baik ideologi, politik, sosial, dan budaya.

Penilaian pengadilan terhadap tindakan BUMN, apakah ia berhak mendapat kekebalan atau tidak, dalam praktek ternyata bersifat sangat kasuistis dan dipengaruhi pula oleh adanya "hubungan baik" dan "hubungan kepentingan" antara pemerintah dimana yurisdiksi pengadilan itu berada dengan pihak-pihak yang terkait dalam kasus tersebut.

13. Ibid., him. 47.
Di masa mendatang, melalui kaidahkaidah hukum internasional perlu ditetapkan semacam general conditions dan guidelines yang akan digunakan sebagai pedoman dalam penerapan prinsip kekebalan negara yang dibentuk atas dasar kesepakatan negara-negara melalui perjanjian internasional.

\section{DAFTAR KEPUSTAKAAN}

A. Hamid S. Attamimi, Badan Usaha Milik Negara Kedudukan Ekonomis-Yuridisnya dan Pengelolaan Keuangannya, Makalah dalam Seminar Nasional Keuangan Negara II, diselenggarakan oleh Jurusan HAN, Fakultas Hukum UI, pada tanggal 28 Pebruari 1991, di Jakarta.

Moses Aldrin Kimuli, The Application of The Doctrine of Foreign Sovereign/State $/ \mathrm{mmu}$ nity to Public Corpora-tion, Lawasia, Journal of The Law Association For Asia and Facific Published by The Faculty of Law. New South Wales Institute of Technology. 1986.

Romadhon K.H. (editor), Otobjografi Soeharto Pikiran, Ucapan, dan Tindakan Saya, PT Cipta Lamtorogung Persada, Cet. II, 1989.

Sompong Sucharitkul, State Immunities and Trading Activities in International Law, Frederick a. Praeger inc., Publisher, New York, 1959.

Sudargo Gautama, Hukum Perdata dan Dagang Intemasional, Alumni, Bandung, 1980.

- Soal-soal Aktual Hukum Perdata Intemasional, Alumni, Bandung, 1981.

- Aneka Masalah Hukum Perdata Intemasional, Alumni, Bandung, 1985.

Yudha Bhakti Ardhiwisastra, Penerapan Sovereign dan Act of State Doctrin Negara Berdaulat di Hadapan Pengadilan Asing. Tesis, UNPAD, Bandung, 1982.

___ Immunitas Negara dan Doktrin Tindakan Negara, Makalah Bahan Penataran Prinsip-Prinsip Hukum Intemasional, FH-UNPAD, Bandung, 16-28 November 1992. \% Ni'matul Huda, SH, adalah alumni FH UII, Kini menjadi dosen pada FH UII
dan sedang menyelesaikan studi S-2 di Universitas Padjajaran Bandung. 